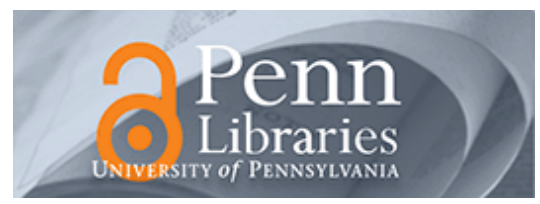

University of Pennsylvania

ScholarlyCommons

2-1-1999

\title{
Changing the Price of Pork: the Impact of Local Cost Sharing on Legislators' Demands for Distributive Public Goods
}

Alison F. DelRossi

Robert P. Inman

University of Pennsylvania

Follow this and additional works at: https://repository.upenn.edu/bepp_papers

Part of the Public Affairs, Public Policy and Public Administration Commons, and the Public Economics Commons

\section{Recommended Citation}

DelRossi, A. F., \& Inman, R. P. (1999). Changing the Price of Pork: the Impact of Local Cost Sharing on Legislators' Demands for Distributive Public Goods. Journal of Public Economics, 71 (2), 247-273. http://dx.doi.org/10.1016/S0047-2727(98)00071-1 


\title{
Changing the Price of Pork: the Impact of Local Cost Sharing on Legislators' Demands for Distributive Public Goods
}

\begin{abstract}
The provision of public services through national legislatures gives legislators the chance to fund locally beneficial public projects using a shared national tax base. Nationally financed and provided local (congestible) public goods will be purchased at a subsidized price below marginal cost and may be inefficiently too large as a consequence. An important assumption behind this inefficiency is that national legislators in fact demand more of the locally beneficial project as the local price for projects declines. This paper provides the first direct test of this important assumption using legislators' project choices following the passage of the Water Resources Development Act of 1986 (WRDA'86). We find legislators' chosen water project sizes do fall as the local cost share rises, with a price elasticity of demand ranging from -0.81 for flood control and shoreline protection projects to -2.55 for large navigation projects. The requirement of WRDA'86 that local taxpayers contribute a greater share to the funding of local water projects reduced overall proposed project spending in our sample by $35 \%$ and the federal outlay for proposed project spending by $48 \%$.
\end{abstract}

\section{Keywords}

pork barrel spending, federal budget, cost sharing, water projects

\section{Disciplines}

Public Affairs, Public Policy and Public Administration | Public Economics 
CHANGING THE PRICE OF PORK:

THE IMPACT OF LOCAL COST SHARING

ON LEGISLATORS' DEMANDS FOR

DISTRIBUTIVE PUBLIC GOODS

\author{
Alison F. DelRossi \\ Robert P. Inman
}

Working Paper 6440 
NBER WORKING PAPER SERIES

\title{
CHANGING THE PRICE OF PORK: THE IMPACT OF LOCAL COST SHARING ON LEGISLATORS' DEMANDS FOR DISTRIBUTIVE PUBLIC GOODS
}

\author{
Alison F. DelRossi \\ Robert P. Inman
}

Working Paper 6440

http://www.nber.org/papers/w6440

\author{
NATIONAL BUREAU OF ECONOMIC RESEARCH \\ 1050 Massachusetts Avenue \\ Cambridge, MA 02138 \\ March 1998
}

Miguel Gouveia, Steven Craig, Tim Groseclose, and Peter Aranson provided helpful comments on an earlier version of this paper. The authors thank Douglas Kamien and Douglas LaMont, and their colleagues and staff of the U.S. Army Corps of Engineers, for help in locating information on water resource projects. For financial support, DelRossi thanks the College of Business, University of Wyoming, and Inman thanks the National Science Foundation for support through a grant to the National Bureau of Economic Research. Any opinions expressed are those of the authors and not those of the National Bureau of Economic Research.

(C) 1998 by Alison F. DelRossi and Robert P. Inman. All rights reserved. Short sections of text, not to exceed two paragraphs, may be quoted without explicit permission provided that full credit, including (C) notice, is given to the source. 
Changing the Price of Pork: The Impact

of Local Cost Sharing on Legislators' Demands

for Distributive Public Goods

Alison F. DelRossi and Robert P. Inman

NBER Working Paper No. 6440

March 1998

JEL No. H4

\section{ABSTRACT}

The provision of public services through national legislatures gives legislators the chance to fund locally-beneficial public projects using a shared national tax base. Nationally-financed, local public goods will be purchased at a subsidized price below marginal cost and may be inefficiently too large as a consequence. An important assumption behind this conclusion is that national legislators in fact demand more of the locally-beneficial project as the local price for projects declines. This paper provides the first direct test of this important assumption using legislators' project choices following the passage of the Water Resources Development Act of 1986 (WRDA'86). We find legislators' chosen water project sizes do fall as the local cost share rises, with a price elasticity of demand ranging from -1.3 for flood control and shoreline protection projects to perhaps as high as -2.5 for large navigation projects. The requirement of WRDA' 86 that local taxpayers contribute a greater share to the funding of local water projects reduced overall project spending in our sample by 35 percent and the federal outlay for project spending by 48 percent.

\author{
Alison F. DelRossi \\ Department of Economics and Finance \\ University of Wyoming \\ Laramie, WY 82071-3985
}

\author{
Robert P. Inman \\ Finance Department \\ Wharton School \\ 3620 Locust Walk \\ University of Pennsylvania \\ Philadelphia, PA 19104-6367 \\ and NBER
}




\section{Introduction}

Given current pressures to control federal deficits and taxation and the political difficulty of cutting entitlements, a popular target of reformers both inside and outside legislatures has been "pork barrel" spending. Pork barrel projects, more formally known as "distributive" public goods (Lowi, 1964), are projects whose benefits are concentrated within a geographic area or identifiable constituent group but whose costs are typically financed through general taxation or government deficits. Even though this type of spending represents a modest portion of most government budgets, it receives much attention, perhaps due to its perception as being politically motivated and economically inefficient. The commonly held proposition is that legislators choose excessive levels of distributive goods spending because their constituents pay such a small share of the goods' overall costs. This paper provides a first direct test of the central behavioral assumption which underlies this conclusion: that legislators demand more distributive goods as their constituents' share of the costs of those goods declines.

Whether one specifies legislative decision-making as "universalistic" (Weingast, Shepsle, and Johnsen, 1981), as "minimal winning coalitions" (Baron, 1993), or as logrolled "supermajorities" (Groseclose and Snyder, 1997), a common assumption in each legislative model is that elected legislators will demand more of a local (i.e., beneficial to constituents) project when the costs of that project are shared with non-local taxpayers. Assuming elected representatives reflect the average demand of their constituents and that there are no significant spillovers from local projects to non-constituents, such financing may lead to inefficiently large public spending for local, distributive goods (Inman and Fitts, 1990, and Coate, 1997). What drives this inefficiency is an assumed non-zero price elasticity of demand for the centrally-financed 
distributive public good and the fiscal "wedge" between social marginal costs and local marginal costs created by central government financing. ${ }^{1}$ When these conditions hold, legislative politics create Harberger "triangles," now known as political economy's "common pool" resource problem. The size of these potential inefficiencies depends crucially upon legislators' price elasticities of demand for local constituent services.

There have been previous efforts to specify and estimate legislators' demands for constituent services and in each case significant negative price elasticities of demand for local services were found, ranging from -0.17 to -5.0 ; see, for example, Inman and Fitts (1990), DelRossi (1995), Gilligan and Matsusaka (1995), and Crain (1997). While a useful beginning, these studies are limited by their use of aggregate data, specifying average legislative spending for distributive goods as a function of an average legislator's "price." Specifying the average price necessarily requires a commitment to an underlying model of legislative decision-making, however. The effective price a legislator perceives herself to pay for constituent services will depend upon how coalitions set budgets within the legislature and upon the size of the winning coalitions; see Inman and Fitts (1990). The estimated price elasticities of demand from such a specification will therefore be conditional estimates, conditional upon a maintained hypothesis as

1 Both conditions are necessary. Weingast's (1979) initial analysis of universalism, for example, fixes the size of local constituent projects demanded by legislators, in effect assuming a zero price elasticity of demand. Niou and Ordeshook (1985) rightly pointed out that with fixed project sizes, universalistic legislatures, if they arise at all, cannot be economically inefficient. Shepsle and Weingast (1981) and Weingast, Shepsle, and Johnsen (1981) anticipated this problem but chose to deal with it by assuming project size, while fixed, is inappropriately valued by legislators who double count economic benefits. The political economy literature now recognizes that legislative inefficiencies can arise without fiscal illusions, but legislators' demands for distributive public gonds must be sensitive to the constituents' price for those services. 
to how the legislature does its budgeting. ${ }^{2}$

A similar specification issue also arose in the early empirical work estimating citizens' demands for local public goods using aggregate spending from cities and school districts. That literature assumed budgets were set by Downsian referendum politics. The resulting median voter was the voter with the median income, and the appropriate price corresponded to this median income voter's share of each marginal dollar of local spending; see Bergstrom and Goodman (1972) and Inman (1979). Romer and Rosenthal (1979) rightly pointed out the conditional nature of the resulting estimates for the price elasticities of demand. The solution in the local public goods literature was to move the analysis from aggregate data to micro data and to estimate demands for local public goods directly from household surveys; see Bergstrom, Rubinfeld and Shapiro (1982). This micro approach removed the need to specify a political model as a means to identifying a household price elasticity of demand. We propose a similar approach here, though we shall be estimating individual legislators' price elasticities of demand, not households'.

To implement our approach we take advantage of a unique natural experiment in legislative budgeting. The Water Resources Development Act of 1986 (WRDA'86) broke a ten year drought in water project authorization in the U.S. Congress but, for the members of the

2 Using U.S. historical data on federal spending for constituent services, Inman and Fitts (1990) and DelRossi (1995) estimate elasticities conditional on either of two legislative regimes, one where the legislatures operate under a norm of universalism -- giving the now familiar $1 / \mathrm{R}$ "price," where $\mathrm{R}$ is the number of legislators -- and another regime, where strong political parties internalize fiscal spillovers across party members, changing the individual legislator price to $M / R$, where $M$ is the number of members in the majority party. Gilligan and Matsusaka (1995) and Crain (1997) both estimate a price elasticity using a cross-section of states regressing state spending on the universalistic price, $1 / R$, where $R$ is the number of legislators in the state House of Representatives. 
legislature, at a cost. Marginal local cost shares for new project funding rose from zero to as much as .50 for large navigation projects and structural flood control projects and from .30 to .35 for smaller shoreline protection projects. Members of Congress were then allowed to adjust the size of their local water projects given the new cost-sharing rules of WRDA'86. We have data on legislators' chosen project sizes, both before and after the WRDA'86 cost-sharing changes. Knowing the change in project sizes and the corresponding changes in local cost shares we estimate the legislators' price elasticity of demand for water projects, holding constant attributes of the projects, the demographics of the affected congressional districts, and the political party and committee status of the legislators.

Section II describes the process of project selection and important changes introduced into water project budgeting by WRDA'86. We then specify how WRDA' 86 budgeting allows us to estimate a legislator price elasticity of demand for congressionally-chosen water projects. Section III provides estimates of the relevant price elasticity and draws conclusions about the impact of increased cost sharing on the size of water project spending. Section IV summarizes our results and comments on their possible implications for managing central government budgets, generally.

\section{An Empirical Model of Project Spending for Water Resources}

\section{A. WRDA'86 as a Natural Experiment}

Federal government spending on Army Corps of Engineers (hereafter, Corps) water resource projects, the stereotypical pork barrel project, has from its inception been the 
responsibility of the congressional legislators whose constituents receive the project benefits. ${ }^{3}$ Since the early 1930 's, the process by which the federal government sets water project spending has remained virtually unchanged. There are six steps which must be followed, and at each step local congressional input is important. In step 1, the locally elected Representative or Senator proposes a local water project to the Corps for review and evaluation. In step 2, Congress provides funding to the Corps to conduct a feasibility study of the proposed project. Feasibility studies typically examine several alternative project sizes or specifications, calculating the economic benefits and costs of each alternative project according to a common methodology (detailed in the federal government's "Green Book" and updated in the 1973 Principles and Standards; see Campen, 1986). In step 3, the member of Congress who originally proposed the project is then free to select a project specification and size, often in consultation with the Corps' evaluation staff. ${ }^{4}$ Step 4 collects a number of locally-approved water projects into a single water bill (e.g., WRDA'86) for authorization by Congress. Passage of an authorization bill means the local project has been approved for funding. In step 5 Congress appropriates spending for the

3 See Maass (1951), Ferejohn (1974), and Reuss (1991) for histories of U.S. water resource spending. The very first water project bill was signed by President Monroe on May 24, 1824 and appropriated $\$ 75,000$ to improve navigation on the Ohio and Mississippi rivers. Reuss comments: "While providing navigation channels on the Ohio and Mississippi rivers was certainly of substantial potential military value, there is little question that this act was passed in response to the urging of western politicians who were interested primarily in commercial expansion" (Reuss, 1991, p. 4).

4 There is a possibility that the Corps can play a significant "gatekeeper" role in this step by offering the member of Congress a simple "take-it-or-leave-it" offer. In fact, quite the opposite seems to be the case; the member of Congress acts as a gatekeeper to the Corps. Today, no project is approved unless it has the blessing of the local Representative or Senator; see Ferejohn $(1974$, p. 55). Ferejohn $(1974$, p. 86) concludes that the "Corps of Engineers correctly considers itself to be a congressional agency..." 
authorized projects, usually as part of omnibus spending bills. As a general rule, most authorized projects are funded, although in tight budget times funding may be spread more thinly, slowing construction. In step 6, project construction begins and continued appropriations lead to the eventual completion of the project. Crucially, locally elected representatives control the specification and scale of projects in steps 1-3. Congress as whole controls which of these locally preferred projects are built in steps 4 and 6.

WRDA'86 was the first major authorization of new water projects since the passage of the Flood Control Act of 1970. However, from 1970 to 1986, members of Congress continued to propose projects (step 1), the Corp continued to evaluate projects (step 2), and new projects were selected by Representatives and Senators (step 3). From the passage of the Flood Control Act of 1970 to WRDA'86, however, only a handful of these new projects were authorized or funded for construction. The rest sat on the shelf. The main roadblock to new funding was the insistence by Presidents Carter and Reagan that any new projects adopted by Congress include an expanded contribution toward the costs of new construction by the local communities benefiting from the project.

Prior to the adoption of WRDA'86, local contributions to project construction consisted largely of donated land, utility relocations, and dredge disposal areas. These so-called "LERRD" contributions (land, easements, right-of-way, relocations, and dredge disposal) were determined by the specifications of the project and were typically met using land and facilities already owned by the city, county, or state governments. Only shoreline protection projects, the smallest of all water projects, required any direct financial contribution (30 percent of project costs) from local governments; see Table 1. Pre-WRDA' 86 cost shares for local governments for our sample of 
projects are reported in Table 1. The reported local cost shares include the LERRD contributions, where donated land is valued by the Corps at fair market value. The preWRDA' 86 local cost shares range from an average of .22 for navigation projects, to .25 for flood control projects, to .55 for shoreline protection projects.

WRDA'86 introduced a required local cost share for all project types, stating that any gap between the required local share and that filled through LERRD contributions must be met by a direct cash contribution from local governments. For the first time, local governments are required to contribute own tax dollars for the construction of all Corps' water projects within their jurisdictions. ${ }^{5}$ Table 1 reports the post-WRDA'86 local cost shares (again, including LERRD's contribution) for our sample of WRDA'86 water projects. The local cost share rose from .22 to .42 for our sample's average navigation project, from .25 to .33 for the average flood control project, but fell from .55 to .39 for the sample's three shoreline protection projects. An examination of these three projects revealed a likely redesign of project specifications from the pre-WRDA'86 to post-WRDA'86 period; while local cash contributions rose as required, the redesigned projects offered smaller LERRD contributions thereby reducing the overall local share.

It was the intention of those promoting increased local cost-sharing to encourage smaller, and presumably, more economically efficient water projects. ${ }^{6}$ Did local cost-sharing have this

5 For navigation projects, there may be an additional cash contribution of 10 percent of construction costs. Non-federal interests can repay the 10 percent over 30 years with interest. However, in the calculation of actual non-federal shares, the Corps assumes the contribution is made in the initial construction year.

6 Richard Walsh, Director of the Office of Economics in the Department of Transportation testified on behalf of the administration's cost-sharing proposal arguing: 
intended effect? WRDA' 86 required the members of Congress whose districts or states received authorized projects to re-negotiate their project sizes and specifications from their pre-WRDA'86 levels -- in effect, to revisit step 3 of water project budgeting. Re-negotiations entailed asking the Corps of Engineers to evaluate a re-specified version of the originally approved project. If the re-specified project still met the Corp's benefit/cost criterion $(B / C \geq 1)$, then the new project could replace the original project in the WRDA'86 authorization list. Members could also tell the Corps to leave their projects at their original, pre-WRDA'86 scales and specifications, but of course their local governments would have to pay the higher, post-WRDA'86 local cost shares for their project. Finally, through inaction, members could effectively drop their project from the WRDA' 86 authorization list. In our sample of 82 projects authorized by WRDA' 86,29 were re-negotiated to a smaller size, 33 to a larger project size, and 20 were voluntarily dropped from authorization by the local representative. Bigger water projects in the post-WRDA'86 sample should not be unexpected. Despite the rise in local cost shares, representatives might still prefer larger projects in 1986 than, say in 1976, if other demand determinants became more favorable to larger projects. Our empirical analysis will control for these other demand determinants so that we can isolate the effect of cost share changes alone.

The record of proposed water project spending before and after WRDA' 86 provides a unique natural experiment for estimating directly a legislator's price elasticity of demand for one

"Effective marketplace decișion-making is very important not only from this Administration's philosophical point of view, but also from the standpoint of the wise and efficient use of our economy's resources. . . . (T)here is no reason why Federal revenues from the general taxpayers should be used to pay the costs of government provided services and facilities when the users of those services are able to meet the costs and there is no overriding social objective to be served by providing a subsidy." (Reuss, 1991, p. 155) 
type of federally-funded, constituent-based public good. Through our sample of observed project sizes and local cost shares both before and after WRDA'86 and changes in other determinants of legislators' demands, we can estimate a legislator's price elasticity of demand for water projects.

\section{B. Specifying Legislators' Demands for Water Projects}

In setting the level of water project spending in their congressional districts, legislators are assumed to balance constituent benefits from additional project spending against constituent costs of that spending. Water projects, specified by a project size $Q$, provide a stream of benefits per constituent $(g)$ dependent on number of project users $(N)$ who share the project and on the various projects' types $(T): \mathrm{g}=\mathrm{g}(\mathrm{Q} ; \mathrm{N}, \mathrm{T})$. Project types $(\mathrm{T})$ include navigation projects (ports and harbors), flood control projects (dams and levees), and shoreline protection projects (breakwaters and erosion control). This public good's technology allows for congestion in the provision of public services -- that is, water projects may be pure (Samuelsonian) public goods $(\partial \mathrm{g} / \partial \mathrm{N}=0)$ or pure private goods $(\partial \mathrm{g} / \partial \mathrm{N}=-\mathrm{g} / \mathrm{N})$. A typical specification for the technology of public service production, and the one we use here, is:

$$
\mathrm{g}=\exp \{\Phi(\mathrm{T})\} \cdot \mathrm{Q} / \mathrm{N}^{\gamma(\mathrm{T})}
$$

where $\gamma(\mathrm{T})$ is the "congestion elasticity" for the provision of water services of type $\mathrm{T}$. If $\gamma(\mathrm{T})=$ 0 then the water project can be considered a pure public good. If $\gamma(T)=1$ then the project is effectively a private good, requiring a proportional increase in $Q$ to hold the level of services 
constant when $\mathrm{N}$ increases.

The marginal benefits enjoyed by a legislator from a small increase in water project services for each constituent who uses the project $(g)$ will depend on the previous levels of services provided to constituents $\left(g_{0}\right)$, a vector of socioeconomic characteristics of the constituents $(\boldsymbol{X})$ which determine how much they value water services, the total number of citizens $(N)$ who benefit from the project, and the type water project $(T)$ being provided: $\mu(\mathrm{g} ; \mathrm{T})$ $=\mu\left(\mathrm{g} ; \mathrm{g}_{0}, \mathbf{X}, \mathrm{N}, \mathrm{T}\right)$. For this analysis, we specify the legislator's marginal benefits from a water project of type $\mathrm{T}$ as $\log$-linear in services $(\mathrm{g})$ :

$$
\mu(g ; T)=\exp \left\{\alpha(\mathrm{T})+\eta \operatorname{lng}_{0}\right\} \cdot \mathbf{X}^{\delta} \cdot \mathrm{N}^{\sigma} \cdot \mathrm{g}^{-\beta(\mathrm{T})}
$$

where currently low levels of water project services $\left(\partial \mu(\mathrm{g}) / \partial \mathrm{g}_{0}<0\right),{ }^{8}$ high constituent demands $(\partial \mu(\mathrm{g}) / \partial \mathbf{X}>0)$, and more citizens receiving benefits $(\partial \mu(\mathrm{g}) / \partial \mathrm{N}>0)$, all increase a legislator's

7 For a careful treatment of this and alternative specifications of public service congestion technologies, see Craig (1987).

8 For convenience we approximate the total level of services from all water projects in a district by the expression $\exp \left\{\mathrm{m} \cdot \operatorname{lng}_{0}\right\} \cdot \mathrm{g}$ rather than the true total level $\left[\mathrm{g}+\mathrm{g}_{0}\right]$. This approximation allows us to keep the model specification in log-linear form. If $\mathrm{g}_{0}$ is very small or zero we can set $\mathrm{g}_{0}=1$ and the approximation becomes $\mathrm{g} \approx 1+\mathrm{g}$. When $\mathrm{g}$ is measured in resources per resident (see eq. (1)), this will a good approximation for any reasonably sized project. For selection of new levels of water project services around large initial values of $\mathrm{g}_{0}$, values of $\mathrm{m}$ can be adjusted so that approximated and true changes are nearly equal--that is, $\mathrm{d}\left[\exp \left\{\mathrm{m} \cdot \operatorname{lng} \mathrm{n}_{0}\right\} \cdot \mathrm{g}\right] / \mathrm{dg} \approx 1$ or $\exp \left\{\mathrm{m} \cdot \operatorname{lng}_{0}\right\} \approx 1$ with the second derivative of $\exp \left\{\mathrm{m} \cdot \operatorname{lng}_{0}\right\}$ near zero. Setting $\mathrm{m}$ equal to a small number, say $\mathrm{m}=.0001$, will satisfy these specifications constraints. This assumed value of $\mathrm{m}$ will have a role to play when we seek to identify water project congestion technologies; see section III below. In the specification above $\eta=-\beta(\mathrm{T}) \cdot \mathrm{m}$, implying $\partial \mu(\mathrm{g}) / \partial \mathrm{g}_{0}<0$. 
marginal benefits from an increase in water services. The elasticity of legislator benefits with respect to $N(\sigma)$ will be close to 1 when all constituents are users and the legislator is interested in maximizing constituents' aggregate surplus. When the number of users $(\mathrm{N})$ exceeds constituents, however, as when there are significant project spillovers to non-constituents, then $\sigma$ $\leq 1$. In the extreme case of a median voter model, $\sigma=0$ and the legislator cares only about the marginal benefits received by that single median voter. Finally, eq. (2) assumes benefits received depend proportionally on project type.

The legislator's marginal benefits can also be expressed in terms of actual project size (Q), our approach here. Substituting (1) into (2) both for service levels from existing projects $\left(\operatorname{lng}_{0}=\Phi(T)+\ln Q_{0}-\gamma(T) \ln N\right)$ and for service levels from new projects, specifies the legislator's marginal benefits from a water project of type $T$ as log-linear in new project size $(Q)$ :

$$
\mu(\mathrm{Q} ; \mathrm{T})=\exp \left\{\alpha(\mathrm{T})+\eta \Phi(\mathrm{T})+\eta \ln \mathrm{Q}_{0}-\eta \gamma(\mathrm{T}) \ln \mathrm{N}-\beta(\mathrm{T}) \Phi(\mathrm{T})\right\} \cdot \mathbf{X}^{\delta} \cdot \mathrm{N}^{\sigma+\beta(\mathrm{T} m(\mathrm{~T})} \cdot \mathrm{Q}^{-\beta(\mathrm{T})}
$$

The marginal costs borne by a legislator from additional water project spending is assumed to equal the costs borne by her constituents, specified to equal the additional taxes which constituents must pay as project size $(Q)$ is increased. Each unit of a water project of type $T$ is assumed to cost a constant $\mathrm{c}(\mathrm{T})$ dollars; total project costs are therefore $\mathrm{c}(\mathrm{T}) \cdot \mathrm{Q}$. These total costs can be paid by direct constituent taxes via a required local cost share, $\phi(T)$, or indirectly through the constituents' share of federal taxes. Local taxes will pay $\phi(\mathrm{T}) \cdot \mathrm{c}(\mathrm{T}) \cdot \mathrm{Q}$ of project costs while federal taxation pays $(1-\phi(T)) \cdot c(T) \cdot Q$. The constituents' share of the federal tax burden depends upon their share of the national tax base. Assuming that federal taxation is approximately 
proportional against income and that a legislator's constituents come primarily from his congressional district, then the constituents' share of the federal tax burden will be approximately $(1 / \mathrm{R}) \cdot\left(\mathrm{Y}_{\mathrm{i}} / \mathrm{Y}\right)$, where $\mathrm{Y}_{\mathrm{i}}$ is the average income in congressional district $i, \mathrm{Y}$ is the national average income, and $\mathrm{R}$ is the number of congressional districts. ${ }^{9}$ Ignoring disparities in district income (i.e., assuming $\left.\mathrm{Y}_{\mathrm{i}} \approx \mathrm{Y}\right)$, each legislator's constituents will therefore pay $(1 / \mathrm{R}) \cdot(1-\phi(T)) \cdot \mathrm{c}(\mathrm{T}) \cdot \mathrm{Q}$ in federal taxation for a project of size $\mathrm{Q}$. Total constituent costs from providing a project of type $\mathrm{T}$ and size $Q$ will equal local costs plus the appropriate share of federal tax costs: $\phi(T) \cdot c(T) \cdot Q+$ $(1 / R) \cdot(1-\phi(T)) \cdot c(T) \cdot Q .^{10}$ The additional costs borne by the legislator's constituents for a small increase in $\mathrm{Q}$ for a project of type $\mathrm{T}$ is therefore:

$$
\kappa(Q ; T)=\phi(T) \cdot c(T)+(1 / R) \cdot(1-\phi(T)) \cdot c(T)
$$

For large values of $\mathrm{R}-\mathrm{e}$.g., $\mathrm{R}=50$ for the U.S. Senators or $\mathrm{R}=435$ for members of the U.S. House -- marginal costs of additional $Q$ is well approximated by:

9 The full specification of constituents' federal tax share is $Y_{i} \cdot C_{i} / Y \cdot \Sigma C_{i}$, where $Y_{i}$ is the average income in constituent group $i, \mathrm{Y}$ is the national average income, $\mathrm{C}_{\mathrm{i}}$ is the number of constituents in constituent group $i$, and $\Sigma C_{i}$ is the national population. For legislatures based upon the principle of equal representation and politics based on district constituencies, $\mathrm{C}_{\mathrm{i}} / \Sigma \mathrm{C}_{\mathrm{i}}=$ $1 / \mathrm{R}$.

10 The specification here ignores the excess burden of local and federal taxation. This omission should not affect our analysis, given that we will study the effects of price changes during a period in which the overall level and structure of local and federal taxation changed very little. Plus, the level of project spending under analysis is small and unlikely to affect the marginal excess burden of taxation. Cross-national, cross-state, or long time series studies of government spending should consider the role of the excess burden of taxation as tax structures are likely to differ significantly in such samples; see Inman and Fitts (1990) and DelRossi (1995) for studies allowing for changes in the excess burden of taxation. 
Balancing the legislator's marginal benefits against her marginal costs defines the legislator's preferred project size. Setting $\left(2^{\prime}\right)=\left(3^{\prime}\right)$ defines the preferred level of $Q(T)$ as:

$$
Q^{*}(T)=\exp \left\{p(T)+q(T) \ln Q_{0}-m(T) \ln N\right\} \cdot X^{d(T)} \cdot N^{n(T)} \cdot[\phi(T) \cdot c(T)]^{-b(T)}
$$

where $p(T)=\alpha(T) / \beta(T)+\eta \Phi(T) / \beta(T)-\Phi(T), q(T)=\eta / \beta(T), m(T)=\eta \gamma(T) / \beta(T), d(T)=$ $\delta / \beta(\mathrm{T}), \mathrm{n}(\mathrm{T})=\sigma / \beta(\mathrm{T})+\gamma(\mathrm{T})$, and $\mathrm{b}(\mathrm{T})=1 / \beta(\mathrm{T})$. Alternatively:

$$
\ln Q^{*}(T)=\left[p(T)+q(T) \ln Q_{0}\right]+d(T) \cdot \ln X+[n(T)-m(T)] \cdot \ln N-b(T) \cdot \ln [\phi(T) \cdot c(T)]
$$

where $\left[p(T)+q(T) \ln Q_{0}\right]$ is a "fixed effect" unique to each project and congressional district and where the coefficient $-b(T)$ is the legislator's price elasticity of demand for water projects of each type T (= navigation, flood control, shoreline protection). The natural experiment of WRDA'86 allows us to use a fixed effects estimator to estimate the coefficients of (4'). For our analysis, $Q$ will be measured as real total construction costs in the pre- and post-WRDA'86 years.

Four measures of constituent users' demands $(\mathbf{X})$ for water projects are included in the analysis, each interacted with project type. In each case, we will measure $\mathbf{X}$ for the county or counties in which the project is located, under the assumption that the primary beneficiaries of 
the water project are local households. ${ }^{11}$ The first $\mathbf{X}$ variable, project users' income, may have several effects on project choice. We approximate users' income by per capita income (Per Capita Income) in the county or counties in which project construction occurs. To the extent water projects are normal public goods, we expect users' incomes to have a positive effect on legislator demand. If water projects are primarily job-creation programs for low income districts, however, then Per Capita Income may have a negative effect on legislators' demands. To test the jobs program hypothesis more directly we also include the county rate of unemployment (Unemployment Rate). We expect navigation projects, rather than flood control or shoreline protection projects, to be the projects most likely motivated by job creation. Apart from any offsetting motives for job creation, users' income should have a positive effect on the legislator's demand for flood control and shoreline protection projects for either or both of two reasons. First, to the extent these projects provide protection against significant economic loss from natural disasters, then higher income households will typically demand more of these protective activities. $^{12}$ Second, if flood control and shoreline protection projects also provide attractive

"For flood control projects we tested for the possibility that residents upstream and downstream from the project might also matter for the specification of project size but found no evidence of this; see note 22 below.

12 Insurance coverage for losses from hurricanes (wind damage) and floods is mandated by federal and state laws or required by lending institutions; see Kunreuther (1996). Coverage is incomplete however, typically requiring a $20 \%$ copay from insurees. Property owners are also at risk for the "sentimental value" of irreplaceable items and the "nuisance losses" from putting one's household or business back in order after a flood or hurricane. Such uninsured losses are a reason to invest in protective activities, i.e., flood control and shoreline protection. Models of households decisions to self-insure through protective actions will give positive income elasticities of demand for such activities when household behavior displays constant relative risk aversion. For some evidence that the income elasticity of demand for property protection is positive, at least as expressed through the demand for police services, see Inman (1979). 
recreation and/or environmental outcomes, then again higher income users should demand more of both project types. ${ }^{13}$ The hypothesis that flood control and shoreline projects provide precautionary investments against property loss is also tested by including two measures of potential losses in X: Median House Value and Percent Urban Land. Median House Value is expected to have a positive effect on the demand for flood control and shoreline projects. Percent Urban Land may have a positive or negative effect, depending on whether damages from floods or hurricanes are greater (positive) or less (negative) in urban areas than in farming areas. We expect no significant effect of Percent Urban Land on legislator's demands for navigation projects. Finally, all four users' demand variables were measured for the affected county(ies) at pre-WRDA' 86 levels for legislator's pre-WRDA' 86 project selections and at post-WRDA' 86 levels for post-WRDA'86 project selections. Income Per Capita and Median House Value were deflated by the national Urban-CPI and the Urban-CPI's housing component, respectively, for the pre- and post-WRDA'86 years. The Appendix provides means and standard errors for these and other variables used in the estimations.

The number of project users $(N)$ is specified as the population of the county or counties in which project construction occurs. $\mathrm{N}$ is the number of possible users of the project and the group most likely to reward the legislator for benefits provided. Project users need not equal the legislator's total political constituency. For relatively small projects, $\mathrm{N}$ can be a subset of all constituents -- say, levees on the Saw Mill River in New York. For large projects or projects

${ }^{13}$ The income elasticity of demand for environmental amenities such as water recreation and endangered habitat/species protection are typically positive. See Freeman (1993) and Braden and Kolstad (1991) for a discussion of various elasticity estimation procedures for non-market, environmental goods. 
with significant spillovers, $\mathrm{N}$ can be greater than any one legislator's constituency -- for example, a navigation project in Baltimore Harbor. When the number of project users exceeds the number of constituents in any single legislator's district, we interpret our estimates of demand as what a coalition of all affected legislators might decide. In most instances, however, each project can be reasonably identified with a single legislator; 48 of our sample of 82 projects have a single representative (58\%) while 34 projects have two (17 projects) or more (17) representatives.

The legislator's marginal cost or price of additional water project spending is specified as the local cost share times the construction cost to build one unit of a water project of type $\mathrm{T}$ : $\phi(\mathrm{T}) \cdot \mathrm{c}(\mathrm{T})$. We measure $\mathrm{c}(\mathrm{T})$ by a city-specific construction cost index for the pre- and postWRDA'86 years $\left(c_{\text {pre }}\right.$ and $\left.c_{\text {poss }}\right)$ in which project sizes were selected, adjusted proportionally by project type: $\mathrm{c}(\mathrm{T})=\exp (\varphi \mathrm{T}) \cdot \mathrm{c}_{\text {preppost }}{ }^{14}$ Pre-WRDA'86 and post-WRDA'86 local cost shares, $\phi_{\mathrm{pre}}(T)$ and $\phi_{\text {post }}(T)$, were available from Corps documents for each of the 82 projects in our sample, except for the 20 authorized projects which were effectively removed from the appropriations list by the project's congressional representative. ${ }^{15}$ Since these projects were not

14 The construction cost index was developed by Haughwout and Inman (1996) based upon city specific data from Engineering News Record for the years of our sample. The HaughwoutInman index excludes the price of land, however, a price that will be unique to each project and its time of construction. If we assume that the production technology for water projects is CobbDouglas, then a fully specified price index including construction costs and land prices will be a Cobb-Douglas (log-linear) function of $c(T)$ and the location and time-specific land prices; see Varian (1978, p. 19). Given our log-linear demand curve specification, the land price component of the fully specified cost index will then become part of our project-specific constant term, as specified in eq. (4') above.

15 To qualify for funding, members of Congress were required to activate a Corps review of their project within five years (1992) of passage WRDA'86 so that a new cost share could be determined. Seven projects were dropped from the authorization list because no member activated the required review. For thirteen other projects, members opened the review process 
completed, the Corps did not formally assign a post-WRDA' 86 local cost share. We predict the 20 missing post-WRDA' 86 cost shares from an estimate of a local cost share equation using the sample of 62 projects for which post-WRDA' 86 shares were available. Estimates control for project type and, for navigation projects, the depth of the navigation channel. ${ }^{16}$

The specification of project demands in eqs. (4 and $4^{\prime}$ ) assumes that each legislator can choose his or her preferred project size. This may not be a valid assumption in a legislature such as the U.S. Congress, where members belong to political parties and where congressional committee memberships may be important determinants of legislative influence. Members of the

but the review was discontinued and never re-started. It is the opinion of the Corps staff we interviewed that these reviews were discontinued because of lack of local interest in continuing the project. In the analysis reported here we treat these 20 projects as having a preferred project size $Q^{*}(T)=0$ in the post-WRDA period. Tobit estimates (not reported in this paper) were done to correct for possible bias due to a censored dependent variable. The results are virtually identical to the OLS estimates reported in Table 2.

16 WRDA' 86 cost sharing rules are explicitly stated in the legislation (Table 1), and the Corps' staff follows these rules when setting each project's new value of $\phi(T)$. The estimated specifications for $\phi_{\text {posi }}(T)$ using the sample of post-WRDA cost shares for the 62 available projects are:

Flood Control and Shoreline Protection $(\mathrm{N}=43)$ :

$$
\begin{aligned}
\phi_{\text {poss }}(\mathrm{T})= & 0.3327+0.0614 \cdot(\mathrm{T}=\text { Shoreline Protection }) \\
& (.0138) \quad(.0521)
\end{aligned}
$$

Navigation $(\mathrm{N}=19)$ :

$$
\begin{aligned}
\phi_{\text {post }}(T)= & 0.2817+0.0036 \cdot(\text { Channel Depth }) \\
& (.1033) \quad(.0026)
\end{aligned}
$$

Standard errors are reported in parentheses. Estimated cost shares are assigned using the $\phi_{\text {post }}(T)$ specifications above for each project type, and the project's post-WRDA' 86 channel depth if the project is a navigation project. Since the Corps evaluates the local government's contributions of land to the project's cost share at local land prices, we included regional dummies to allow for possible variation in local land prices across regions but these were statistically insignificant (individually and as a group) for these small subsample estimations. 
minority party and members not on key water policy committees may be discriminated against when submitting their preferred project sizes for authorization by Congress; see Ferejohn (1974, Chapters 8 and 9). If so, actual project size may be smaller than the legislator's preferred project size. We shall control for the possible influence on project size of a member's congressional status through a proportional shift from $Q^{*}(T)$ specified as:

$$
\begin{gathered}
\mathrm{Q}(\mathrm{T})=\exp (\rho \mathbf{L}) \cdot \mathrm{Q}^{*}(\mathrm{~T}), \text { or: } \\
\ln \mathrm{Q}(\mathrm{T})=\rho \mathbf{L}+\ln \mathrm{Q}^{*}(\mathrm{~T})
\end{gathered}
$$

where $\mathbf{L}$ is a vector of indicators of the member's status in Congress. We assume the crucial member for purposes of setting project size is the project's Representative in the House; see Fenno (1966; p. 503) and Ferejohn (1974; pp. 113-115). L includes whether the project's representative is a member of the House minority party at the time of project selection (Republican $=1$ if the member belongs to the Republican Party; 0 otherwise), and whether the member is a "floor member" for purposes of water projects. Floor Member will equal 1 if the representative is lacking membership on a key House water project committee and 0 otherwise. ${ }^{17}$ The key water committees we propose are the Public Works and Transportation (selecting water projects), Armed Services (supervising the Corps), Interior and Insular Affairs (overseeing western state issues), and Merchant Marine and Fisheries (dealing with trade and navigation issues) committees. If a member's congressional status does affect the chosen project size, then

17 In the case of large projects affecting more than one House Representative, Republican will equal 1 if any Representative was a Republican, and Floor Member will equal 1 only if all affected Representatives lack membership on a key House water committee. 
Republican and Floor Member will have negative effects on $Q(T)(\rho<0) .{ }^{18}$

\section{Sample and Estimation}

WRDA'86 authorized 254 new start water construction projects covering 270 different congressional districts at a total cost of about $\$ 22.9$ billion. The 254 authorized projects were selected from a list of 339 projects which had been submitted by members of Congress and approved for authorization by the Corps between the passage of the last major water project authorization bill in 1970 (Flood Control Act of 1970) and the passage of WRDA'86. These 339 feasible projects covered 314 congressional districts. Thus, WRDA' 86 approved 75 percent of all feasible projects, authorizing spending in 86.9 percent of those congressional districts eligible for support. Under WRDA'86 nearly every House member who wanted a water project and whose project had met the Corps benefit/cost test $(\mathrm{B} / \mathrm{C} \geq 1)$ got one. In this regard, WRDA'86 was no different than its many predecessors (Ferejohn (1974); p. 20).

The sample for this study consists of 62 water projects authorized by WRDA' 86 for which re-negotiated project sizes were available as of September, 1992 (the end of our sample period). Also included in our sample are 20 projects authorized in WRDA'86 whose members and/or local governments indicated the project was no longer desired. The 82 projects represent $32 \%$ of the 254 authorized projects but account for almost $44 \%$ of the total construction costs

18 This specification for the possible effects of member status on project size is functionally equivalent to adjusting upward the "effective price" faced by minority or floor members when they select their project sizes. That is, we could specify the effective price of a water project as $\exp (\lambda \mathbf{L}) \cdot \phi(\mathrm{T}) \cdot c(\mathrm{~T})$, where the leadership imposes a "shadow cost" $(\lambda>0)$ on minority members and floor members when they select their projects; see Inman and Fitts (1990) or Baron (1993). Under this specification, $Q(T)=\exp (-b(T) \lambda \mathbf{L}) \cdot Q^{*}(T)=\exp (\rho \mathbf{L}) \cdot Q^{*}(T)$, where now $\rho=-b(T) \lambda$ $<0$. 
authorized in WRDA'86. Data on project sizes, cost shares, and project characteristics before and after WRDA'86 was developed for each individual project from Corps reports and interviews; see DelRossi (1993) for details. For our analysis the projects are grouped into two broad project types: $\mathrm{T}=$ navigation $(27$ projects) or flood control/shoreline protection (55 projects, only 3 of which are shoreline protection).

Project size $(\mathrm{Q})$ is estimated as total proposed pre- and post-WRDA'86 project spending deflated by the construction cost index for the pre- and post-WRDA' 86 years in which the project size was proposed. ${ }^{19}$ For our full sample of 82 projects, the mean pre-WRDA' 86 project size (1993 dollars) was $\$ 107.4$ million or approximately $\$ 554 /$ resident in the congressional districts receiving a project. The mean post-WRDA'86 project size (1993 dollars) was $\$ 70.1$ million or approximately $\$ 302 /$ resident. On average, navigation projects are the largest projects, both before and after WRDA'86. The average navigation project size before WRDA'86 was $\$ 182.6$ million (\$694/resident) falling to $\$ 85.7$ million (\$380/resident) after WRDA'86, while the average flood control/shoreline protection project size before and after WRDA'86 was $\$ 70.5$ million ( $\$ 485 /$ resident) and $\$ 62.4$ million ( $\$ 264 /$ resident), respectively. As a share of private income in these congressional districts, water project spending is significant, equaling .045 (= $\$ 584 / \$ 12,246)$ of income in the pre-WRDA'86 period and $.021(=\$ 302 / \$ 14,083)$ of income in the post-WRDA' 86 period. For comparison, annual state and local government investment as a

$19 \mathrm{Q}$ will be mismeasured as our construction cost index omits land prices, but total project spending includes expenditures on land. Thus, our deflated $Q$ systematically overstates true project size roughly in proportion to the missing land price component of project costs. The fact that our demand specification in eq. $\left(5^{\prime}\right)$ is log-linear, however, allows us to account for this proportional mismeasurement through a project specific constant term which helps control for variation in the price of land. Estimates of our price elasticity of demand will remain unbiased, despite possible measurement error in our dependent variable (Malinvaud, 1966, p. 328). 
fraction of personal income averaged .02 over our sample period.

Eqs. $\left(4^{\prime}\right)$ and $\left(5^{\prime}\right)$ will be estimated using a fixed effect estimator which allows for constant terms for each project to control for project- and location-specific attributes that do not vary over time and are not accounted for by $\mathbf{X}, \mathrm{N}, \mathrm{L}$, or $\phi(\mathrm{T}) \cdot \mathrm{c}(\mathrm{T})$. Eq. $\left(4^{\prime}\right)$ estimates the legislator demand model ignoring members' legislative status; eq. (5') allows for the possibility that legislative status may affect chosen project size. Equation errors are assumed to be normally distributed with mean 0 and constant variance.

Two potential estimation issues arise from the specification of the local cost share variable. First, for navigation projects the post-WRDA'86 local cost share varies with the depth of the channel; see Table 1. This suggests a "kinked" budget line along the dimension of channel depth, and the possible need for a full-information maximum likelihood estimator which makes endogenous the choice of the segment of the budget line along which project size is chosen (see Moffitt, 1984). For half of our sample's navigation projects, however, channel depth did not change following the introduction of the post-WRDA'86 cost shares, despite changes in their project sizes. For those navigation projects where project depth did change, none of the projects altered their depth by more than a few feet, all the adjustments were to increase channel depth, and no adjustment moved the project to a lower post-WRDA'86 local cost share. We take this as evidence that channel depth was not an economic or political choice variable, but rather a technological necessity dictated by the terrain of the harbor or riverway. If so, channel depth and thus the post-WRDA' 86 local cost shares for each navigation project can be taken as exogenous to project size. Adjustments such as choice over channel length or width, number of docks, and the facilities constructed at each dock are endogenous and result in changes in project size. 
There is a second source of possible endogeneity affecting the local cost share variable. Both the pre- and post-WRDA' 86 cost shares require local governments to contribute the land necessary for the project's completion, the so-called LERRD contribution to the local cost share. If the production technology used to build the project is a constant-returns-to-scale CobbDouglas technology, then land's share of total project costs will be a constant for each project; see Varian (1978, p. 19). In this case, the rate of LERRD's contribution will also be constant, and thus the local cost share will remain exogenous as well. This may not be the case for project technologies other than Cobb-Douglas, however. When the share of land expenditures in total costs varies with project size, the rate of LERRD contributions and thus the local cost share will be endogenous. There are other exogenous determinants of land's share in project costs, however, such as project technologies, land prices, and other factor costs. ${ }^{20}$ When estimating eqs. $\left(4^{\prime}\right)$ and $\left(5^{\prime}\right)$ we shall test for the exogeneity of the rate of LERRD contributions and local cost shares using region, indicator dummy variables for year of project selection, and population density as possible exogenous determinants of project technologies, land prices, and factor costs.

20 Land's share of total project costs, and thus the rate of LERRD contributions, equals $\mathrm{p}_{\text {land }} \cdot \mathrm{LAND}(\mathrm{T}) / \mathrm{c}(\mathrm{T}) \cdot \mathrm{Q}(\mathrm{T})$, where $\mathrm{Q}(\mathrm{T})$ is the size of a project of type $\mathrm{T}, \mathrm{c}(\mathrm{T})$ is the average cost for that project type, $p_{\text {land }}$ is the price of land, and LAND(T) is the amount of land required to build a project of size $\mathrm{Q}(\mathrm{T})$. Generally, the share of land costs in total project costs may vary with project size. For example, when the required amount of land for a project is fixed, then as the project size increases, land's share in total project costs and the rate of LERRD contribution declines. If the technology of water project production is Cobb-Douglas, then land's share of total costs, and thus LERRD, will be constant; see Varian (1978, p. 19). If the project technology is a Leontief fixed coefficient technology in the use of land -i.e., LAND(T)/Q(T) is constant -- then LERRD varies not with project size but only with variations in the ratio of the exogenous factor prices $\left(\mathrm{p}_{\text {land }} / \mathrm{c}(\mathrm{T})\right)$. The project specific constant term controls for variations in $\mathrm{p}_{\text {land }}$, and $\mathrm{c}(\mathrm{T})$ in our model. 


\section{Local Cost Sharing and Legislator's Demand}

Table 2 presents the estimates of legislators' demands for water projects, excluding the possible influence of legislative status on demands. Table 2, column (1) gives ordinary least squares (OLS) estimates of demand as specified by eq. (4'); Table 2, columns (2) and (3) provide the fixed effect estimates. The fixed effect estimator assigns a project specific intercept to each water project; slope coefficients estimate the effect of changes in the independent variables $(\Delta(\phi c), \Delta \mathbf{X}, \Delta \mathrm{N})$ on changes in project size $(\Delta \mathrm{Q})$ within each project. Table 3 presents fixed effect estimates of the influence of changes in legislative status $(\Delta \mathbf{L})$ on changes in project size $(\Delta \mathrm{Q})$, again within each project. While estimated coefficients differ across estimation techniques, a consistent story emerges. Of central importance to us here: legislators' price elasticity of demand for water projects is negative, large, and statistically significant for all but a small subset of navigation projects.

Of the four measures of constituents' demands for water projects $(\mathbf{X})$ only Per Capita Income and (in the OLS estimates only) Percent Urban Land were statistically significant, although Unemployment Rate (+ for navigation) and Median Home Value (+ for flood control/shoreline protection) had their expected estimated effects. The most striking result here is the strong and statistically significant negative effect of Per Capita Income on project size, particularly for navigation projects using the fixed effect estimator (Table 2, col. (2)). From these fixed effect estimates, a $6 \%$ decline in Per Capita Income ${ }^{21}$ will increase the size of flood control/shoreline project by $17.6 \%(=-6 \% \cdot-2.94)$ and the size of a navigation project by $78.5 \%$

${ }^{21}$ For more than $20 \%$ of our projects, real per capita income declined over the pre- to postWRDA period. The average decline for these projects was 6 percent. 
$(=-6 \% \cdot[-2.94+-10.15])$, holding all else constant. We interpret this strong within-project response to a fall in constituent income as a signal that water projects, and in particular navigation projects, are fundamentally federal jobs programs for declining areas.

The OLS results permits an estimate of the effects of user population $(\mathrm{N})$ on project size (Q) and from those estimates we can provide an upper bound estimate for the congestion elasticity $\gamma(\mathrm{T})$ for water projects; see eq. (1). $\mathrm{N}$ does not change sufficiently from the preWRDA' 86 to post-WRDA' 86 period for individual projects to permit an estimate of the effect of $\Delta \mathrm{N}$ on $\Delta \mathrm{Q}$ using the fixed effect estimator; $\mathrm{N}$ is therefore omitted in Table 2, columns (2) and (3). From eq. (4'), the estimated coefficient on $N$ equals $[n(T)-m(T)]=\sigma / \beta(T)+\gamma(T)-$ $\eta \gamma(\mathrm{T}) / \beta(\mathrm{T})$, evaluated for each project type $(\mathrm{T})$. Assuming reasonable values for $\sigma$ and $\eta$, (which give the effects of $\mathrm{N}$ and $\mathrm{g}_{0}$ on legislators' marginal benefits, respectively) and given an estimate of $\beta(T)$ we can place a bound on $\gamma(T)$. For example, for navigation projects, the estimated coefficient on $\mathrm{N}$ is $0.1937(=1.0166-0.8229)$. This implies $\gamma(\mathrm{T})=[0.1937$ $\sigma / \beta(T)] /[1-\eta / \beta(T)]$. Since $\sigma \geq 0$ and $\beta(T) \geq 0$ from eq. (2) and $-\eta / \beta(T)>0$ and likely small (see note 8), the congestion elasticity for navigation projects will be no larger than 1937 (and not statistically different from 0 ). In our sample, navigation projects appear to be close to pure public goods.

In contrast to navigation projects where additional users do not require significant increases in project size to hold project benefits constant, flood control/shoreline protection benefits are significantly and negatively affected by the number of project users. Flood control/shoreline protection projects have 1.0166 as their estimated reduced form elasticity of Q with respect to $N(1.0166=[n(T)-m(T)])$. This implies $\gamma(T)=[1.1472-\sigma / \beta(T)] /[1-\eta / \beta(T)]$. 
Again, the value of $-\eta / \beta(T)$ is positive and small (note 8 ), thus $[1-\eta / \beta(T)] \approx 1$. The OLS (Table 2 , column 1) estimated price elasticity of demand for flood control/shoreline projects is $-\mathrm{b}(\mathrm{T})=$ -.72 which implies $\beta(T)=1.39(=1 / \mathrm{b}(\mathrm{T})$; see eq. (4)). If legislators' preferences for water projects internalize the benefits received by all users, then $\sigma=1$ and the value of $\gamma(\mathrm{T})=[1.0166$ - $1 / 1.39]=.30$. In this case, we conclude that flood control/shoreline projects are "quasipublic" goods. If legislators' preferences are determined only by the benefits received by a single decisive voter (e.g., median voter), then $\sigma=0$, and the estimated congestion elasticity is 1.0166 and not statistically different from 1 , implying flood control/shoreline protection projects are effectively private goods. ${ }^{22}$

Finally, we turn to the main focus of the empirical work -- the responsiveness of legislators' demands to changes in local cost shares. The results show statistically significant, and quantitatively important, negative price elasticity's of demand for all project types except for river channel navigation projects. For estimation, navigation projects were furthered classified as either "deep draft" navigation (large, ocean based harbors), "shallow draft" (modest ocean- or

22 We also tested one extension of this congestion specification for flood control projects: the possibility that for the number of potential upstream and downstream "users" might also influence the chosen project size. Upstream users (number of residents in towns within 50 miles of the affected county's(ies') border) might prefer smaller projects to minimize upstream flooding from the project, while downstream users (number of residents in towns within 50 miles of the affected county's(ies') border) might prefer larger projects to better manage downstream water flow. These effects would be important if flood control externalities are significant and legislators build coalitions to internalize those externalities. We found that the number of upstream and downstream users are quantitatively and statistically insignificant determinants of project size. The estimated elasticities of project size with respect to the number of upstream users and downstream users were 0.0007 (s.e. $=0.0009$ ) and -0.0001 (s.e. $=0.0001$ ), respectively. Such results are consistent with Ferejohn's (1974) conclusion that water projects are fundamentally designed to benefit local constituents. 
river-based harbors), or river channel projects. River channel projects are typically small projects connecting two waterways with only limited supporting infrastructure. Deep draft and shallow draft navigation projects generally involve significant supporting infrastructure. In our sample of 27 navigation projects, there are 6 deep-draft projects (represented as Navigation $=1$; Deep-Draft Navigation $=1 ;$ Shallow-Draft $=0$ ), 18 shallow-draft projects $($ Navigation $=1 ;$ Deep-Draft $=0 ;$ Shallow-Draft Navigation $=1)$, and three river channel projects (Navigation $=$ 1; Deep-Draft $=0$; Shallow-Draft Navigation $=0$ ). From the OLS estimates $($ Table 2, col (1)), the legislator's price elasticity of demand for flood control/shoreline projects is -0.716 ; for deep-draft navigation projects elasticity is $-2.492(=-.716+.759-2.535)$; for shallow-draft navigation projects it is $-0.962(=-.716+.759-1.005)$; and for river channel projects it is $0.043(=.716+.759)$, though this elasticity is not statistically different from 0 . From the fixed effects estimates (Table 2, col. (2)), the legislator's price elasticity of demand for flood control/shoreline projects is -1.273 ; for deep-draft navigation projects it is $-2.554(=-1.273+$ $1.647-2.928)$; for shallow-draft navigation projects it is $-1.207(=-1.273+1.647-1.581)$; and for river channel projects elasticity it is $.374(=-1.273+1.647)$ though again not statistically different from 0 . The estimated price elasticities change very little when we omit the interactions of project type with constituent variables $(\mathbf{X})$ and users $(\mathrm{N})$; see Table 2, col. (3).

Eq. (4') was re-estimated using instrumental variables to allow for the possible endogeneity of the local cost share through the LERRD component of $\phi c$. The instruments for $\ln (\phi c)$ included log of population density, nine (Census) region dummy variables, and interactions of density with the regional dummies and with indicators of project-selection year. Using a 
Spencer-Berk test ${ }^{23}$ on the subsamples for which local cost shares were observed (the full sample and by project type), we could not reject the null hypothesis that the local price, $\phi c$, is exogenous. This is consistent with our assumption that LERRD's contributing share of total cost is fixed (e.g., a Cobb-Douglas production function).

Our estimates of the legislators' price elasticities of demand for water projects are also immune to the introduction of control variables for the legislative status of each project's representative; see Table 3. If history of water project budgeting in the 1960's is our guide, then minority party members (Republican) and members not on key water committees (Floor Member) should get smaller water projects; see Ferejohn (1974; Chapters 8 and 9). There is no evidence in WRDA'86 that changes in legislative status had a significant effect on the size of authorized water projects. Districts which changed the party of their representatives or whose representatives left (or were not appointed to) key water committees (Public Works, Armed Services, Interior, or Merchant Marine) continued to receive their legislator's preferred project sizes. ${ }^{24}$

${ }^{23}$ The Spencer-Berk test requires a two-stage regression. Specifically, for our model, in the first stage we used the instruments described in the text and all other exogenous variables in the system to find a fitted value for $\ln (\phi c)$. In the second stage, $\ln (\mathrm{Q})$ was regressed against all the exogenous variables, including $\ln (\phi c)$, as well as the fitted value of $\ln (\phi c)$ from the first stage. Due to the insignificance of the coefficient on the fitted value of $\ln (\phi c)$ - the coefficient was 0.560 with a standard error of 0.411 for the sample with all project types - we cannot reject the exogeneity of $\ln (\phi c)$. Similar results were found for samples of individual project types. See Kmenta, 1986, pp. $717-718$ or Greene, 1993, pp. 618-619, for details on the Spencer-Berk test.

24 A more detailed look at how changes in committee membership affected the size of authorized projects revealed none of the individual committee coefficients to be statistically significant in a fixed effects specification: Public Works $=-0.3730$ (s.e. $=1.1408$ ), Armed Services $=-0.9921$ (s.e. $=1.2177$ ), Interior $=0.1669$ (s.e. $=1.2278$ ), and Merchant Marine 
The estimated price elasticities allows us to shed some light on an important institutional question: Did the imposition of required local cost-sharing have a significant effect on the size of the final water bill and the allocation of project costs between the federal and local sectors? For our sample of 82 projects, the answer is clearly yes; see Table 4. Table 4.A, entitled Project Spending, details the changes in total projects costs and the changes in the allocation of these costs between federal and local governments from the pre- to post-WRDA' 86 budgets. Had WRDA' 86 been "business as usual" in water project spending, the 82 projects would have been authorized at their pre-WRDA' 86 spending levels and the total cost of this 82 project budget would have been $\$ 8.806$ billion. WRDA' 86 changed two key aspects of project budgeting. First, it increased the local cost share. Second, it allowed the legislators to adjust project sizes from pre-WRDA' 86 levels in response to the change in the local cost share and to other changes in the political $(\Delta \mathrm{L})$ or economic $(\Delta \mathbf{X})$ environment. The combined effect of these changes was to reduce total project spending for the 82 projects from the pre-WRDA'86 level of $\$ 8.806$ billion to the actual post-WRDA' 86 level of spending of $\$ 5.747$ billion, a reduction in project spending of $\$ 3.059$ billion or 35 percent. The federal portion of project spending net of local

$=0.2932$ (s.e. $=1.2155$ ). There are three possible explanations for why our results differ from Ferejohn's generally strong pro-committee results. First, Ferejohn's analysis excludes important constituent demand determinants which are positively correlated with project size and committee assignment. Our analysis includes constituent demand variables $(\mathbf{X})$ and (further) uses a fixed effect estimator thereby avoiding possible omitted variable bias to the committee coefficients. Consistent with this hypothesis, we found near significant and positive coefficients for some committees when not controlling for fixed effects. Second, Ferejohn's analysis includes several water bills which allows him to examine a richer set of policy outcomes not just authorized project size. Perhaps where committee status matters most is in the number of projects received over many years or the size of appropriation each year and thus the speed with which projects are completed -- outcomes not available in our analysis of this single water bill; see also Hird (1991). Third, congressional budgeting from 1986 to 1992 may be different from congressional budgeting in the 1960 's; committee status matters less today than then. 
cost sharing fell even more, from $\$ 6.836$ billion pre-WRDA' 86 to $\$ 3.548$ billion post-WRDA'86 for a total federal budget saving of $\$ 3.288$ billion. The additional $\$ .229$ billion in federal savings was the net "transfer" of costs from the federal government to the local government because of the higher rate of local cost sharing. For our sample of 82 projects the average local share of water project costs rose from '.24 in the pre-WRDA' 86 budget to .36 in the post-WRDA'86 budget.

Table 4.B, entitled Decomposition of Federal Savings, disaggregates the total federal savings of $\$ 3.288$ billion into that portion due to changes in the local cost shares, $\Sigma \Delta \phi \cdot Q$, and into that portion due to changes in project sizes, $\Sigma(1-\phi) \cdot \Delta \mathrm{Q}$. The decomposition computes the contribution of the increase in local cost shares using the pre-WRDA'86 project sizes and computes the contribution of the decrease in project sizes using post-WRDA'86 federal cost shares. In effect, had WRDA'86 simply altered the local cost share but not allowed legislators to alter their project sizes $(\Delta Q=0)$, the bill would have saved $\$ 1.637$ billion from these 82 projects. By also allowing legislators to adjust their project sizes in response to the higher local cost shares, WRDA'86 saved the federal budget an additional $\$ 1.651$ billion.

\section{Conclusion}

National legislatures give locally elected representatives access to a national tax base, and therefore an implicit subsidy, when financing locally beneficial public goods. When representatives are free to choose the level of centrally-financed, locally-beneficial public goods, there will be a tendency to choose a level of provision greater than the collectively-efficient level.

One solution is to have the legislators' constituents pay a greater share of the marginal costs of 
these local goods, a share which seeks to match the share of local benefits in total benefits. For instance, if a project benefits only local constituents, then local constituents should pay all the project's costs.

This analysis of legislative inefficiency, and the recommendation to adjust local cost shares as a corrective policy, is built upon the implicit assumption that legislators are responsive to their constituents' share of project costs when selecting project sizes: lower local shares leads legislators to choose larger projects. We have provided the first direct test of this assumption using the unique natural experiment provided by the Water Resources Development Act of 1986. WRDA'86 raised the local cost shares of water projects and then allowed legislators to adjust pre-WRDA'86 project sizes in response to the new, higher local cost shares. The WRDA'86 experiment provides evidence that higher local cost shares will substantially reduce legislators' demands for locally beneficial projects. The estimated price elasticities of demand ranged from 1.273 for flood control and shoreline protection projects, to -1.207 for shallow-draft navigation projects, to -2.554 for the large deep-draft navigation projects. Only for the small river channel projects in our sample was the estimated price elasticity of demand statistically and quantitatively insignificant. These micro-data panel estimates are broadly consistent with the price elasticities obtained by DelRossi (1995) using aggregate time-series data. ${ }^{25}$ Together, WRDA'86's increase in local cost shares reduced total project spending for our sample from $\$ 8.806$ billion to $\$ 5.747$ billion (a 35 percent decline) and reduced the federal share of project spending from $\$ 6.836$ billion to $\$ 3.548$ billion (a 48 percent decrease). For water projects at least, local cost shares

${ }^{25}$ Shabman and Dickey (1986) also examine the effects of WRDA'86 on four navigation projects and find an estimated arc elasticity of -0.26 . However, they do not control for other factors that may have led to increased project sizes over time. 
matter.

More generally, WRDA'86's imposition of local cost sharing on national legislators represents a new way of conducting central government fiscal policy. From the evidence presented here, local cost sharing successfully encourages central government legislators to assume responsibility for local project costs as well as local project benefits. The hope is that a more efficient balancing of budgetary costs and benefits will occur. This new fiscal policy instrument will likely prove most useful in those instances in which the central government has significant production advantages in the provision of the public service because of scale economies or technological expertise but where the benefits of the project itself are largely local. In this case, local citizens should contract with the central government to provide the public service, but local citizens should pay the costs of the provided service. When such "contracting" is done through a central government legislature, then local cost sharing becomes the means by which local taxpayers can pay for the provided service. Further, if there are positive spillovers from local provision, the local cost share can be reduced to encourage greater local provision. Water projects might be such an example.

Local cost sharing for centrally funded public goods may have an even greater role to play in developing economies, where the production and cost control advantages of central over local governments are likely to be even greater. Local cost-sharing coupled with locally-elected representatives to the national legislature can be a first step towards responsible decentralized budgeting in these economies. For example, locally elected representatives can be given a significant say in the level of local services provided by the central government; local cost sharing can be used to ensure those representatives internalize the costs of the services provided 
to local residents. However, since efficient local government taxes may not yet exist, central government tax administrators must be able to assign national income tax payments by residency. Again, the local cost share can be adjusted to reflect significant positive spillovers from local services. For countries wishing to move from exclusively central government budgeting to a more decentralized fiscal system, but now lack a network of efficient local governments, the introduction of local cost sharing into central government budgeting becomes a potentially useful first reform. Showing that local cost sharing can play this policy role may be the most significant contribution of WRDA'86. 


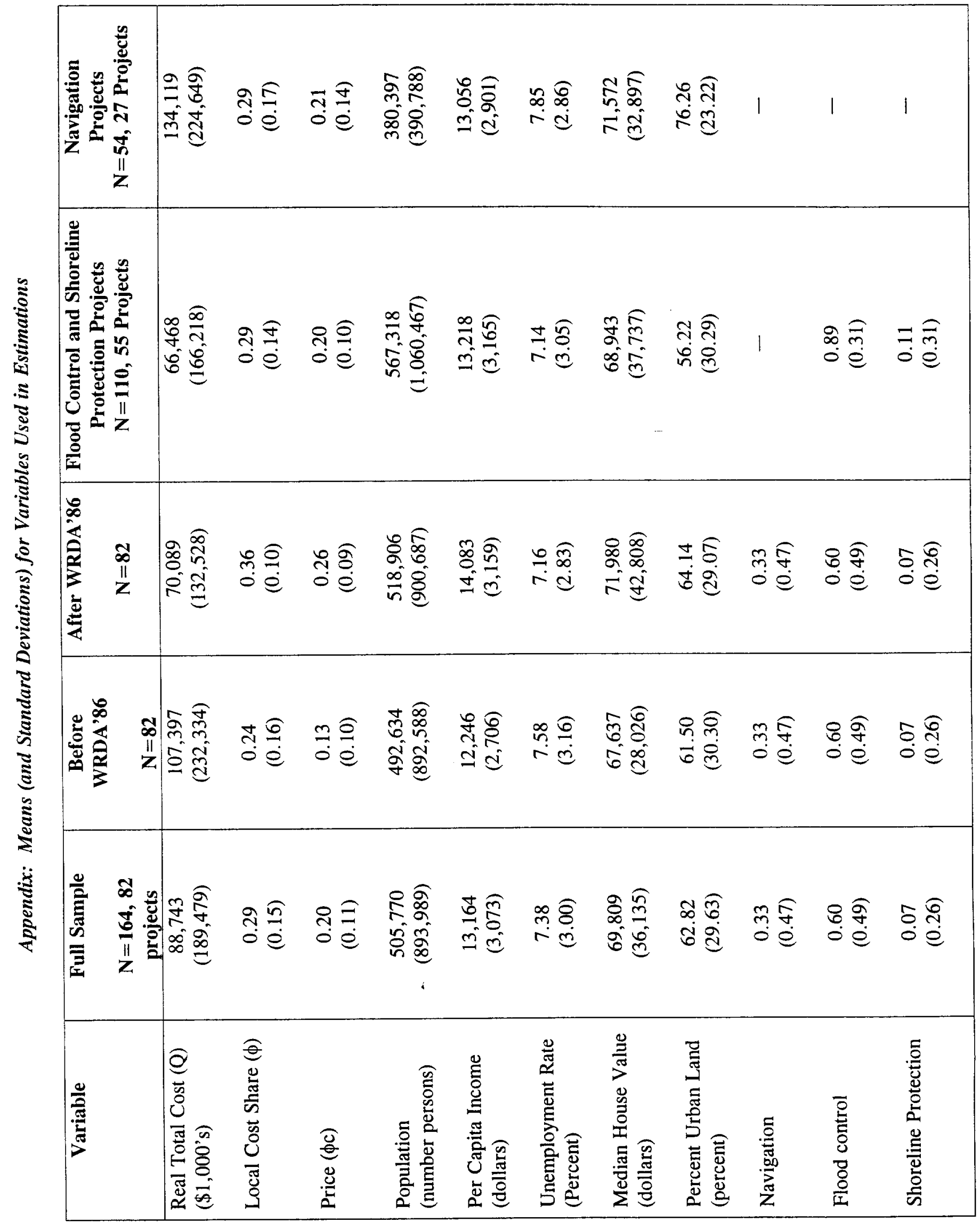




\section{REFERENCES}

Baron, D. (1993), "A Theory of Collective Choice for Government Programs," Graduate School of Business, Stanford University, WP 1240.

Bergstrom, T. and R. Goodman (1972), "Private Demands for Public Goods," American Economic Review, 63(3): 280-296.

Bergstrom, T., D. Rubinfeld, and P. Shapiro (1982), "Micro-based Estimates of Demand Functions for local School Expenditures, "Econometrica, 50 (4), 1183-1205.

Braden, J.B. and C.D. Kolstad (eds.) (1991), Measuring the Demand for Environmental Quality, Amsterdam: Elsevier.

Campen, J.T. (1986), Benefit, Cost, and Beyond: The Political Economy of BenefitCost Analysis, Cambridge: Ballinger.

Coate, S. (1997), "Distributive Policy-Making and Welfare in a Representative Democracy," Department of Economics, University of Pennsylvania, Working Paper.

Craig, S. (1987), "The Impact of Congestion on Local Public Good Production," Journal of Public Economics, 32 (3), 331-353.

Crain, W.M. (1997), "Districts, Diversity and Fiscal Biases: Evidence from the American States," Center for Study of Public Choice, George Mason University, Working Paper.

DelRossi, A.F. (1995), "The Politics and Economics of Pork Barrel Spending: The Case of Federal Financing of Water Resources Development," Public Choice, 85: 285-305.

DelRossi, A.F. (1993), "Three Essays in the Federalism of Water Policy," unpublished Ph.D. dissertation, University of Pennsylvania.

Fenno, R. (1973), The Power of the Purse, Boston: Little, Brown and Company.

Ferejohn, J.A. (1974), Pork Barrel Politics: Rivers and Harbors Legislation, 19471968, Stanford: Stanford University Press.

Freeman, A.M. III (1993), The Measurement of Environmental and Resource Values: Theory and Methods, Washington, D.C.: Resources for the Future.

Gilligan, T.W. and J.G. Matsusaka (1995), "Deviations from Constituent Interests: The Role of Legislative Structure and Political Parties in the States," Economic Inquiry, 33: 383-401. 
Greene, W.H. (1993), Econometric Analysis, New York: MacMillan.

Groseclose, T. and J. Snyder (1996), "Buying Supermajorities," American Political Science Review, 90 (2), 303-315.

Haughwout, A. and R. Inman (1996), "State and Local Assets and Liabilities, 19721992," Wharton School, University of Pennsylvania, Working Paper.

Hird, J.A. (1991), "The Political Economy of Pork: Project Selection at the U.S. Army Corps of Engineers," American Political Science Review, 85: 429456.

Inman, R. (1979), "The Fiscal Performance of Local Governments: An Interpretative Review," in P. Mieszkowski and M. Straszheim (eds.), Current Issues in Urban Economics, Baltimore: Johns Hopkins University Press.

Inman, R.P. and M.A. Fitts (Special Issue, 1990), "Political Institutions and Fiscal Policy: Evidence from the U.S. Historical Record," Journal of Law. Economics and Organization, 6: 79132.

Kmenta, J. (1986), Elements of Econometrics, 2nd Edition, New York: MacMillan.

Kunreuther, H. (1996), "Mitigating Disaster Losses Through Insurance," Journal of Risk and Uncertainty, 12 (2), 171-187.

Lowi, T. (1964), "American Business and Public Policy, Case Studies and Political Theory," World Politics 16 (3), 677-715.

Maass, A. (1951), Muddy Waters: The Army Engineers and the Nation's Waters, Cambridge: Harvard University Press.

Malinvaud, E. (1966), Statistical Methods of Econometrics, Chicago: Rand McNally.

Moffitt, R. (1984), "The Effects of Grants-in-Aid on State and Local Expenditures: The Case of AFDC," Journal of Public Economics, 23 (3), 279-305.

Niou, E. and P. Ordeshook (1985), "Universalism in Congress," American Journal of Political Science, 29 (2), 246-260.

Reuss, M. (1991), Reshaping National Water Politics: The Emergence of the Water Resources Development Act of 1986, Washington, D.C.: Institute for Water Resources (IWR Policy Study 91 PS 1).

Romer, T. and H. Rosenthal, "The Elusive Median Voter," Journal of Public Economics, $12(2), 143-170$. 
Shabman, L. and G.E. Dickey (1986), "Federal Financial Responsibility for Coastal Port Development: A Study of the Process of Policy Redefinition," Policy Studies Review, 6: 358365 .

Shepsle, K.A. and B.R. Weingast, (1981), "Political Preferences for Pork Barrel: A Generalization," American Journal of Political Science, 25: 96111.

Varian, H. (1978), Microeconomic Analysis, New York: W.W. Norton and Co.

Weingast, B.R., K.A. Shepsle, and C. Johnsen (1981), "The Political Economy of Benefits and Costs: A Neoclassical Approach to Distributive Politics, "Journal of Political Economy, 89: 642664. 


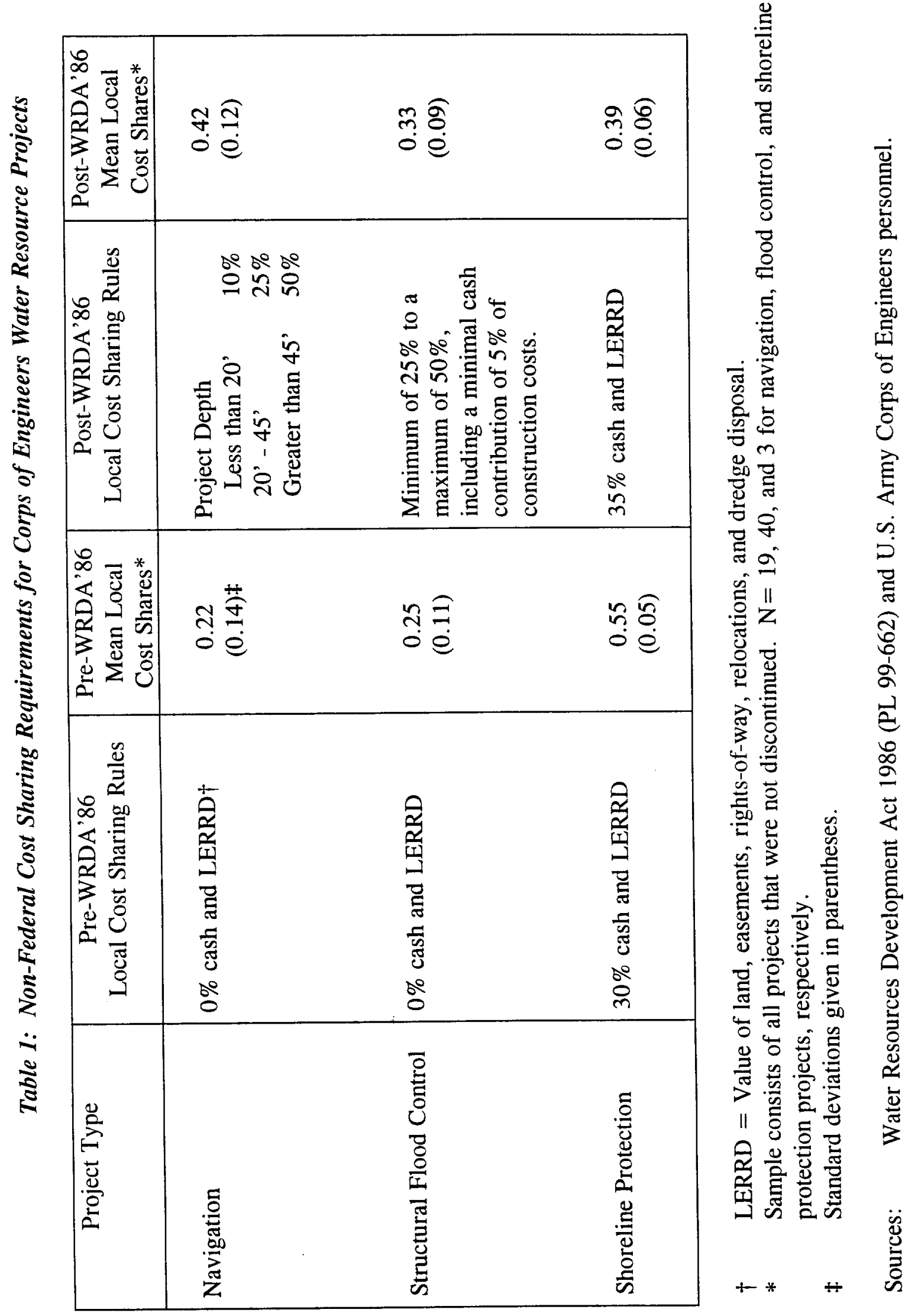


Table 2: Legislator's Demand for Water Resource Projects Dependent Variable: $\ln (Q)$

\begin{tabular}{|c|c|c|c|}
\hline \multirow[b]{2}{*}{ Independent Variable } & \multirow{2}{*}{$\begin{array}{c}\text { OLS } \\
(1) \\
\end{array}$} & \multicolumn{2}{|c|}{ Fixed Effects } \\
\hline & & $(2)$ & (3) \\
\hline Constant & $\begin{array}{c}-9.5310 \\
(19.4431) \dagger\end{array}$ & $\ddagger$ & $\ddagger$ \\
\hline Navigation Project & $\begin{array}{c}45.2743 \\
(32.1756)\end{array}$ & & \\
\hline $\ln (\phi c)$ & $\begin{array}{l}-0.7155^{*} \\
(0.3050)\end{array}$ & $\begin{array}{l}-1.2726^{*} \\
(0.3396)\end{array}$ & $\begin{array}{l}-1.1348 * \\
(0.3228)\end{array}$ \\
\hline $\ln (\phi c) \times($ Navigation Project $)$ & $\begin{array}{c}0.7593 \\
(0.4828)\end{array}$ & $\begin{array}{c}1.6472 * \\
(0.5785)\end{array}$ & $\begin{array}{c}1.1718^{*} \\
(0.5091)\end{array}$ \\
\hline $\ln (\phi c) \times($ Deep-Draft Navigation Project) & $\begin{array}{l}-2.5353^{*} \\
(0.7435)\end{array}$ & $\begin{array}{l}-2.9277^{*} \\
(1.2892)\end{array}$ & $\begin{array}{l}-2.7764^{*} \\
(1.2409)\end{array}$ \\
\hline $\ln (\phi c) \times($ Shallow-Draft Navigation Project $)$ & $\begin{array}{l}-1.0048^{*} \\
(0.5085)\end{array}$ & $\begin{array}{l}-1.5812^{*} \\
(0.9248)\end{array}$ & $\begin{array}{l}-2.2153^{*} \\
(0.7598)\end{array}$ \\
\hline $\ln (\mathrm{N})$ & $\begin{array}{c}1.0166^{*} \\
(0.3252)\end{array}$ & & \\
\hline Navigation $\times \ln (\mathrm{N})$ & $\begin{array}{l}-0.8229 \\
(0.6118)\end{array}$ & & \\
\hline In(Per Capita Income) & $\begin{array}{l}-1.0490 \\
(2.0797)\end{array}$ & $\begin{array}{l}-2.9450 \\
(3.0715)\end{array}$ & $\begin{array}{l}-5.6807^{*} \\
(2.6053)\end{array}$ \\
\hline Navigation $\times \ln ($ Per Capita Income $)$ & $\begin{array}{l}-5.2332 \\
(3.7612)\end{array}$ & $\begin{array}{r}-10.1541^{*} \\
(5.7824)\end{array}$ & \\
\hline Unemployment Rate & $\begin{array}{l}-0.0183 \\
(0.1234)\end{array}$ & $\begin{array}{l}-0.1979 \\
(0.1770)\end{array}$ & $\begin{array}{l}-0.1578 \\
(0.1528)\end{array}$ \\
\hline Navigation $\times \ln ($ Unemployment Rate $)$ & $\begin{array}{c}0.0162 \\
(0.2230)\end{array}$ & $\begin{array}{c}0.2959 \\
(0.3734)\end{array}$ & \\
\hline $\ln ($ Median House Value) & $\begin{array}{c}1.4301 \\
(0.9950)\end{array}$ & $\begin{array}{c}1.7608 \\
(2.0913)\end{array}$ & $\begin{array}{c}1.4642 \\
(1.8070)\end{array}$ \\
\hline Navigation $\times \ln ($ Median House Value $)$ & $\begin{array}{c}0.8662 \\
(2.2555)\end{array}$ & $\begin{array}{l}-1.5146 \\
(4.1529)\end{array}$ & \\
\hline Percent Urban Land & $\begin{array}{l}-0.0131 \\
(0.0124)\end{array}$ & $\begin{array}{c}0.1032 \\
(0.1020)\end{array}$ & $\begin{array}{c}0.1278 \\
(0.0946)\end{array}$ \\
\hline Navigation $\times \ln ($ Percent Urban Land $)$ & $\begin{array}{r}0.0513^{*} \\
(0.0244)\end{array}$ & $\begin{array}{l}-0.0035 \\
(0.2903)\end{array}$ & \\
\hline $\mathrm{R}^{2}$ & 0.2517 & 0.4594 & 0.4240 \\
\hline
\end{tabular}

\$ Project-specific constant terms available from the authors. † Standard errors given in parentheses.

* Statistically significant at the $10 \%$ level or lower. 
Table 3: Political Status and Legislative Demand

Dependent Variable: $\ln (Q)$

\begin{tabular}{|c|c|c|c|}
\hline \multirow[b]{2}{*}{ Independent Variable $\ddagger$} & \multicolumn{3}{|c|}{ Fixed Effects Model } \\
\hline & (1) & (2) & (3) \\
\hline $\ln (\phi c)$ & $\begin{array}{l}-1.29630^{*} \\
(0.3455) \dagger\end{array}$ & $\begin{array}{l}-1.2753^{*} \\
(0.3426)\end{array}$ & $\begin{array}{l}-1.2928^{*} \\
(0.3427)\end{array}$ \\
\hline $\ln (\phi c) \times($ Navigation Project $)$ & $\begin{array}{c}1.6083 * \\
(0.5906)\end{array}$ & $\begin{array}{c}1.6512^{*} \\
(0.5834)\end{array}$ & $\begin{array}{c}1.6075^{*} \\
(0.5847)\end{array}$ \\
\hline $\ln (\phi c) \times($ Deep-Draft Navigation Project $)$ & $\begin{array}{l}-2.7352^{*} \\
(1.3446)\end{array}$ & $\begin{array}{l}-2.9290^{*} \\
(1.2984)\end{array}$ & $\begin{array}{l}-2.7339^{*} \\
(1.3329)\end{array}$ \\
\hline $\ln (\phi c) \times($ Shallow-Draft Navigation Project $)$ & $\begin{array}{l}-1.5216 \\
(0.9419)\end{array}$ & $\begin{array}{l}-1.5841^{*} \\
(0.9316)\end{array}$ & $\begin{array}{l}-1.5208^{*} \\
(0.9342)\end{array}$ \\
\hline Republican & $\begin{array}{c}0.0160 \\
(0.9226)\end{array}$ & $\begin{array}{c}0.1202 \\
(0.9016)\end{array}$ & \\
\hline Floor Member & $\begin{array}{c}0.5367 \\
(0.8858)\end{array}$ & & $\begin{array}{c}0.5296 \\
(0.8633)\end{array}$ \\
\hline $\mathrm{R}^{2}$ & 0.4623 & 0.4595 & 0.4623 \\
\hline $\begin{array}{l}\text { F-Statistic, Testing Political Variables } \\
(\mathrm{r}, \mathrm{N}-\mathrm{K})\end{array}$ & $\begin{array}{c}0.12 \\
(3,67)\end{array}$ & $\begin{array}{c}0.01 \\
(1,69)\end{array}$ & $\begin{array}{c}0.37 \\
(1,69)\end{array}$ \\
\hline
\end{tabular}

$\ddagger$ Regressions also control for $\mathbf{X}$ variables given in Table 2. Project-specific constant terms available from authors.

$\dagger$ Standard errors given in parentheses.

* Statistically significant at $10 \%$ level or lower. 
Table 4. Did Increased Local Cost Sharing Shrink the WRDA'86 Budget?

\begin{tabular}{|c|c|c|c|}
\hline \multicolumn{4}{|c|}{$\begin{array}{l}\text { 4A. Project Spending } \\
\text { Millions of Dollars (Percent of Total Spending) }\end{array}$} \\
\hline $\begin{array}{l}\text { Sum of Project } \\
\text { Costs }\end{array}$ & $\begin{array}{l}\text { Pre-WRDA'86 } \\
\text { Cost Sharing }\end{array}$ & $\begin{array}{l}\text { Post-WRDA'86 } \\
\text { Cost Sharing }\end{array}$ & $\begin{array}{l}\text { Savings from Increased } \\
\text { Cost Sharing }\end{array}$ \\
\hline Total Costs & $\$ 8,806(100 \%)$ & $\$ 5,747(100 \%)$ & $\$ 3,059(100 \%)$ \\
\hline Federal Costs & $6,836(77.6 \%)$ & $3,548(61.7 \%)$ & $3,288(107 \%)$ \\
\hline Local Costs & $1,970(22.4 \%)$ & $2,199(38.3 \%)$ & $-229(-7 \%)$ \\
\hline \multicolumn{4}{|c|}{$\begin{array}{l}\text { 4B. Decomposition of Federal Savings } \\
\text { Millions of Dollars (Percent of Federal Savings) }\end{array}$} \\
\hline Federal Savings & & $\phi \mathbf{Q}$ & $\sum(1-\phi) \Delta Q$ \\
\hline$\$ 3,288$ & $\$ 1,6$ & $(49.8 \%)$ & $\$ 1,651 \quad(50.2 \%)$ \\
\hline
\end{tabular}

